\section{Academic freedom in Greece}

SIR - I wish to report a development in Greece that represents a flagrant violation of academic freedom. The conservative government has passed a law with barely any debate essentially abolishing the university reform act of 1982 . This law has been passed despite the overwhelming protests of university rectors, faculty and students. It is offered as a "modernization" of the higher education system, but in effect it takes us back to the Middle Ages.

About 18 months ago, the education minister asked the university community for its views on the then-existing law (reform act of 1982). Although the questionnaire was criticized, because in many of the multiple choice questions all available choices, except "other", were variations of those that the minister himself favoured, the minister later admitted that the majority of respondents did not want any changes.

The 1982 act allowed collective government of the universities by administrators, faculty and students, but the minister of education has opted for a scheme where most decisions are made by one person (rector, chairman of a department).

The 1982 act allowed for all faculty positions to be potentially tenure-track, with the two lower positions (lecturer and assistant professor) nontenured and the two higher (associate professor and professor) tenured, thus allowing the younger generation of scholars to do research and to be assessed on the basis of their performance. The result has been a tremendous increase in scholarly work, as a cursory look in the Science Citation Index will show, since the junior faculty were no longer under the immediate authority of the professor. With the new law a freeze is put on all promotions, while positions at the junior level are no longer tenure track, but temporary. In a country with very little employment in the private sector for scientists with PhDs, this is tantamount to scaring younger scientists away from a university career. Tenure positions under the new law will be announced every four years, and the exact allocation per discipline, department and school is to be decided by the minister himself. So instead of worrying about doing their academic jobs well, the younger faculty must vie with each other to become favourites.

As if that were not enough, the new law mandates part-time faculty as well as "full-time but not exclusive" faculty, a contradiction in terms. While the 1982 reform act established full-time faculties, it unfortunately did not prohibit outside employment, which for those in the professions can be very lucrative. Indeed, the new law seems to attack those who take to heart the full-time principle of university work, and strive day after day for the betterment of Greek higher education. For many of the older professors, their job is a ticket to the social circuit, and many of them are barely conversant with their subject.

Last but not least, under the new law, students will now have to pay for their books, except those who are poor or whose parents are tax-dodgers. This will certainly force book prices sky high, not to mention the danger of reverting to the days when the purchase of the professor's expensive but worthless text at a specified bookshop was often the gateway to passing his course.

I can only venture that this new law is intended to result somehow in "private universities" springing up all over the land. This idea was half-tried last year, when the previous minister of education quietly allowed several unscrupulous individuals to open such "universities", charging enormous fees and being nothing more than rented buildings with a few rooms, with many of the old professors lending their names to such monstrosities for "prestige". While the government was ridiculed over this disastrous attempt at privatization, the new law seems simply to be a more refined approach in the hopes of returning to the good old days.

Many universities have now been taken over by the students in protest, and the faculty associations are boycotting examinations. No one knows what will become of the universities, but the minister and the 13 wise old professors behind this new law can take pride in having put back Greek higher education a few decades. After all, the minister himself has yet to venture to a European Communities education ministers' meeting after 18 months on the job, so can we expect him to know any better?

\section{Emmanuel Papamichael}

Department of Chemistry,

University of loannina.

48110 loannina,

Greece

\section{Polish pollution}

SIR - Recent correspondents have drawn attention to air pollution as a possible cause of lung cancer and other diseases $^{1-3}$. But many Western epidemiologists have never been confronted with the degree of air, water and soil pollution affecting Eastern European countries. I live in Upper Silesia, southern Poland, a heavily populated region where air pollution has reached unprecedented levels. In Upper Silesia, there is continued exposure to high and constant concentrations of suspended particulates, PAHs, $\mathrm{SO}_{2}, \mathrm{NO}_{2}$, phenol, formaldehyde, metals and so on, and the level of exposure to, for example, benzo $(a)$ pyrene in ambient air exceeds by a factor of 3-5 the level of a passive smoker ${ }^{4}$. Cluster-type mortality from lung and larynx cancer (as also cancer at other sites) was noted in Silesia by the epidemiological section at our institute (B. Zemla, unpublished observations). In the most polluted part of Silesia, the standardized mortality index from lung cancer in men amounts to 117 deaths per 100,000 (compared with the Polish 'average' of 69). This illustrates the usefulness of 'mapping' in small areas of cancer incidence or mortality in the search for aetiological factors compared with using 'average' numbers for a wider region, and raises the question of what is responsible for such geographical differences.

"Project Silesia", supported by the Environmental Protection Agency (EPA), recently reported high cancer risk due to coke oven emissions in Ostrava and Frydek-Mistek (the Czechoslovak part of Silesia). There are only scant data indicating a possible synergistic interaction between cigarette smoking and air pollution. Interactions between various causative factors (cigarette smoking, radiation, former infections, environmental or work-place pollutants) deserve further study.

Roughly one child in six in central Silesia suffers from a chronic upper respiratory tract disease. What are the consequences? Rearrangements of chromosomes, a high rate of sister chromatid exchange, mitotic arrest and a high level of DNA adducts were found in a pilot study of Silesian inhabitants as compared to rural control group ${ }^{5-7}$. Are these findings meaningless for human health?

To begin to understand the complex basis of lung cancer, we need to know not only how much people smoke, but also the quality of air that people have been breathing all their lives, as well as information about familial risk factors.

Mieczys/aw Chorazzy

Department of Tumour Biology, Institute of Oncology,

44-100 Gliwice,

Poland

1. Paoletti, P. et al. Nature 355, 290 (1992)

2. Wolff, S. P. Nature 356, 471 (1992).

3. Goldsmith, J. R. Nature 358, 706 (1992).

4. Chorazy, M., Szeliga, J., Strózyk, M., Cimander, B. Env. Health Hith Persp. (in the press).

5. Hemminki, K., Grzybowska, E., Chorazy, M. et al. in Complex Mixtures and Cancer Risk (eds Vanio, $\mathrm{H}$., Sorsa, M. \& McMichael, A. J.) 104, 181-192 (IARC Sorsa, M. \&
Lyon, 1990)

6. Motykiewicz, G. et al. Mutat. Res. 260, 195-202 (1991).

7. Nature 360, 256 (1992) 